\title{
Innovation Cluster Creation and Problems of Managers Formation in Universities
}

\author{
Nataliya Klimova \\ Department of Information Systems and Technologies, National Research University Higher School of Economics, \\ Nizhny Novgorod, Russia \\ Email: nklimova@hse.ru
}

Received September 25, 2013; revised October 25, 2013; accepted October 31, 2013

Copyright (c) 2014 Nataliya Klimova. This is an open access article distributed under the Creative Commons Attribution License, which permits unrestricted use, distribution, and reproduction in any medium, provided the original work is properly cited. In accordance of the Creative Commons Attribution License all Copyrights @ 2014 are reserved for SCIRP and the owner of the intellectual property Nataliya Klimova. All Copyright (C) 2014 are guarded by law and by SCIRP as a guardian.

\begin{abstract}
We present here the results of our research study for the role of different forms of training university managers. It is shown as the part of statistical study that MBA forms are preferable. Moreover, it is shown that such results are much the same with entrepreneurships' studies. We explain such phenomena because the dynamic environment of media is similar.
\end{abstract}

\section{KEYWORDS}

\section{Education Programs; Universities Management; Entrepreneurships Training}

\section{Introduction}

In a highly competitive modern world, a key problem faced by practically every organization is the essence and the content of human resource strategies of the effective company [1-3]. The solution of this problem is impossible without a strongly developed system and solid approaches towards the human resources preparation, a very important factor for organizational competitiveness which is present in all functional areas of business: technology, marketing, finance etc. [4].

All chief executives claim that their employees are their greatest assets and the investor community and Government have already recognized that how organizations develop and manage their workforce has become a priority in assessing corporate value. In recent years, increasing attention has been paid to what creates value or delivers excellence in a more-service and knowledgebased economy. Maximizing productivity or efficiency from financial or fixed capital assets is becoming harder and increasingly the focus is put on what is termed "intangible assets” in general and human resources in particular. People can add huge potential value to organization, but tapping this source of value requires both management (and not by chance HR professionals begin to play a leading role in business community) and high le- vels of their education and constant upgrading [5,6].

Russian business community whose presence in the world free market society is not very long begins to acquire the notion of high-quality human factor competitive importance too. At the same time, the awareness of impossibility to obtain it without a strong, systematic and highly-developed business education approaches grows. This part of the work analyzes some problems of business post-graduate education development [7]. In the present Russian business education, a strategic approach to creating a stable competitive advantage is required. Without searching for indices of such competitive advantage, one may lose the competitive struggle. It is necessary to determine strategic horizons: when a close horizon is planned, then the current situation is compared to an available trend, which is based on the part of an entity. In this case, such an entity becomes the hostage of the past.

All trends are fast flowing and the orientation at a long-time horizon (2020) is more urgent: the horizon of strategic vision, namely, the vision of the future, the perception of the company success, the mission. It enables us to hold the purpose of the company activity. It is necessary to look at the current situation in the business education development from the position of the strategic vision and to realize what strategic gaps are to be bridged 
at present for reaching the desired future. First of all, it is necessary to bridge strategic gaps in the sphere of resources and technologies.

Once this work has been done, you may proceed to a mean horizon. The mean horizon forms business models: how to provide for the cash flow generation; the inflow of customers etc. The principal solutions associated with the business model construction will ensure success on the strategic vision horizon. It is further necessary to retain the integrity of activities and the stability of cash flows. The question arises: how shall we form such a business model, which might not be repeated? There is a difficulty: it is an iterative process. As soon as we realize strategic tasks, our vision of the future will change! A strategic process is practically continuous. In the authors' opinion under crisis conditions, there will be prospects for research schools of business applying available innovations in the structure of universities. The main difficulty is in the need of a new competence in activities of business schools, which implies the concentration of interesting teachers with interesting programs. Besides, for the functioning of the system, some new financial environment is required:

1. The profit center is in fast changing programs as a peculiar matrix structure, which enables managing teachers in new programs.

2. Teachers of quite a new formation aimed at their continuous upgrade should work at business schools that are able to fit in and to adjust to new requirements as "Life-long learning" education throughout all the life.

3. Taking into account changes that have taken place for the recent 3.5 - 5 years in the sphere of administration, finance, marketing, human resources management in universities system, the re-promotion of educational services is also required.

\section{Methodology}

Based on the research carried out at the School of Business of Higher School of Economics-Nizhny Novgorod, Russia the most active info dissemination channel is the opinion of kiths and colleagues about the School of Business. These are partners, trainees, guests of the MBA program who have visited presentations or the MBA club named "Regional Strategies" (46 persons in total). Thus $64 \%$ of the respondents are men and $36 \%$ are women. Among the questioned persons $8.9 \%$ of the respondents are aged 20 - 25, 37.8\% are between 26 and 30 years old, $31.1 \%$ are between 31 and 35, 17.8\% are between 36 and 40 and $4.4 \%$ are aged over $40.51 \%$ of the respondents have technical education, $31 \%$ of them have economical and $18 \%$ liberal education. Among the questioned respondents there prevail company executives (20\%) and midlevel managers (22\%). Company owners and line managers are $11 \%$ each, $18 \%$ of the respondents are chiefs of a large independent unit, 9\% of the respondents are functional managers and specialists respectively quite a great information flow is disseminated via Internet site of the MBA program.

To study motivation aspects in teaching managers under the MBA (Master of Business Administration) program of extended education (on the base of the School of Business) such research methods were used as questionnaire and interview (depth interview).

The results obtained in the course of the said research are presented hereinafter as diagrams. The question on a place where a real MBA Diploma may be obtained has been answered by the most respondents (42\%) that it is no matter what country such MBA Diploma is issued in.

\section{Results}

The research participants are convinced that the main criteria of the good business education are the quality of teaching and the teaching staff. But a slightly less number of the respondents (38\%) suppose that a true MBA Diploma may be obtained only in a western business school. 20\% respondents have answered in support of Russian educational institutions, $16 \%$ of them would give preference to a native business school only provided that it applies western methods. According to the quiz carried out at business schools $26.7 \%$ of respondents believe that the MBA Degree is necessary first of all to those who wish to get system knowledge and skills in the sphere of administration, $22.2 \%$ suppose that the said degree is intended for those who strive not only for a career but also for their professional growth. $13.3 \%$ of trainees are sure that the MBA degree is necessary to mid-level managers and top managers, $11.1 \%$ think that this Degree is for those who desire to obtain quick promotion (Figures 1 and 2).

The rest opinions have been divided as follows: the MBA Degree is necessary to those who wish to change their professional specialization (8.9\%); to top managers only $(6.7 \%)$; to managers who wish to make a career in western companies (4.4\%); to managers of large companies (4.4\%).

According to the data of the inquiry carried out with learners of business schools $2.2 \%$ of them believe that the MBA program is just a tribute to the fashion. It proves the fact that managers make a conscious step and strive first and foremost for achieving success in career, in self-realization, in getting new knowledge and experience. The research carried out at business schools shows that in companies the development of managers is not considered as urgent. It is declared by $38 \%$ of learners, $27 \%$ of respondents answer that training in their companies is of episodic, occasional character, $22 \%$ of them say that training is carried out from time to time, when necessary. A unified system of managerial staff retraining 


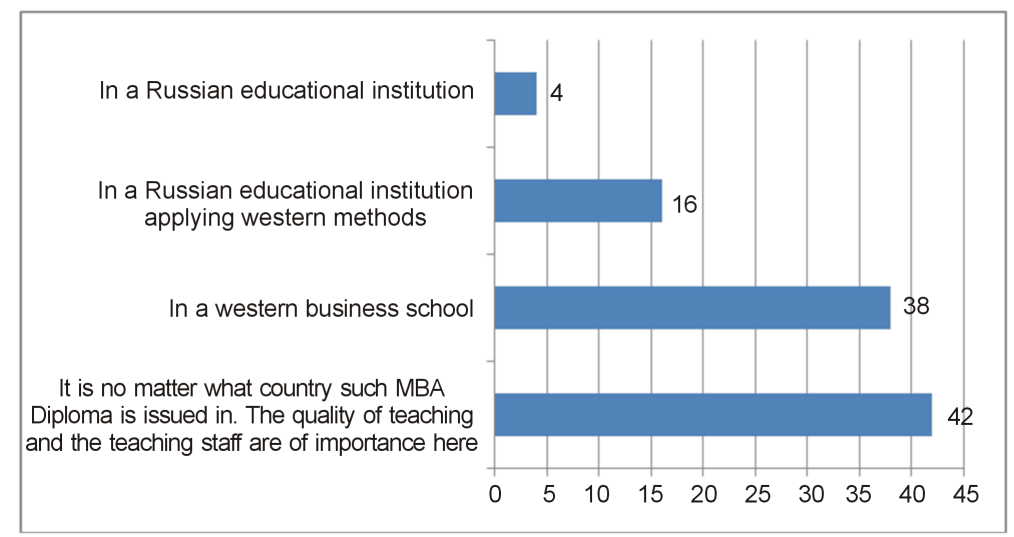

Figure 1. Where a real MBA Diploma may be obtained?

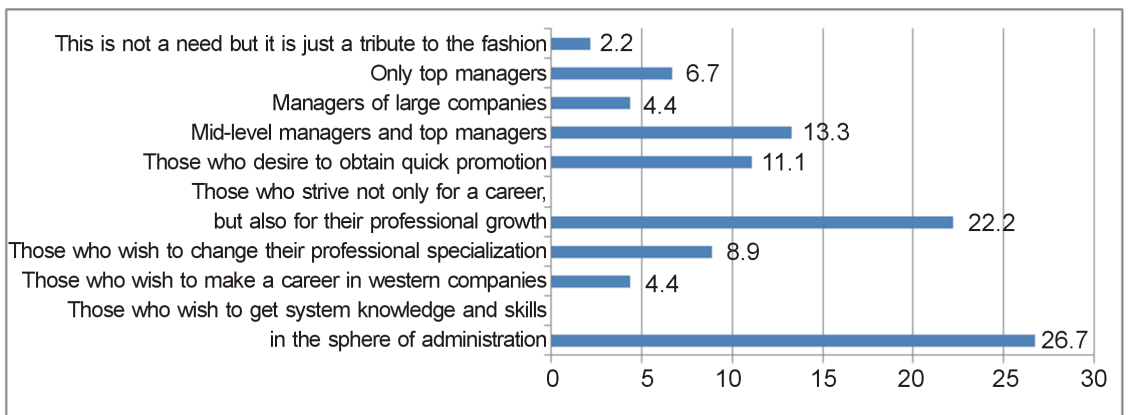

Figure 2. Who needs the MBA degree? (\%)

is available in companies of $11 \%$ of trainees, and only $2 \%$ of respondents answer that in their company there is the company's educational institution.

As for the question about the attitude of the administration towards the training under the MBA program, the following diametrically opposite views appear to be the predominant opinions: the management supports the prospective managers' desire to study (28.9\%) and almost indifferent attitude of executives to training of their employees for the MBA degree (24.4\%). 31.1\% of respondents have stated in questionnaire that their executives recommend to prospective employees to study for the MBA degree. The top-managers of the companies which employ $6.7 \%$ of the inquiry participants display their cautious attitude and only $4.4 \%$ speak about their administrators' explicitly negative attitude (Figures 3 and 4).

And $4.4 \%$ could not assess the attitude of their executives to the training of employees under the MBA program. One of the most interesting questions of the research is the assessment of capabilities for making a career by a manager with the MBA Degree: $6.7 \%$ of the inquiry participants have not been able to assess that factor either for lack of managers with the MBA Degree in their company or for any other reasons. But those who have their own opinion on that matter believe that the MBA degree would hardly influence such manager's promo- tion (6.7\%) and $2.2 \%$ have declared that the availability of the said degree has no effect on making a career. A half of the respondents (48.9\%) suppose that the rate of promotion for managers with the MBA Degree is higher than for managers without the MBA Degree. None of the inquiry participants has stated that the rate of promotion in service for managers with the MBA Degree is lower than for managers without it. And 35.6\% of the respondents believe that having completed the study under the MBA program managers often leave their company.

It appears that a decisive factor in the selection of the MBA program is the practical return to training (29\%). For $22 \%$ of learners the possibility for on-the-job study in the convenient mode is of great importance. For $20 \%$ of the inquiry participants the good name and image of an educational institution is significant (Figures 5-8).

Such an aspect as the cost of training is important in the choice of the MBA program for $18 \%$ of the respondents. Recommendations of colleagues and friends pay an essential role for $11 \%$ of the respondents. During the training under the MBA program $27 \%$ of the respondents obtain new knowledge, $24 \%$ of them systemize their available knowledge. For $20 \%$ of trainees the MBA degree is the opportunity for solving certain business problems and $16 \%$ of them believe that the MBA Degree is either the chance for the career development (7\%) or the possibility for changing the sphere of activities (9\%). The 


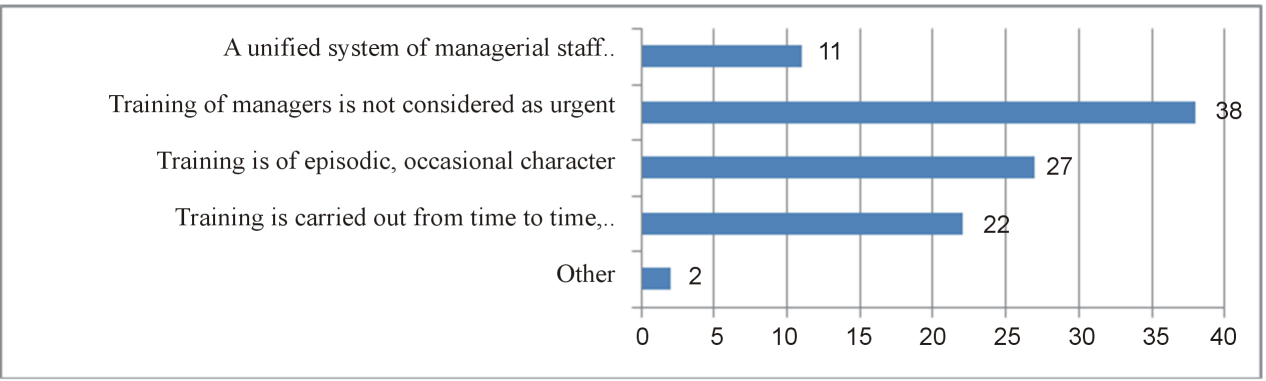

Figure 3. What kind of training system is there in your company? (\%)

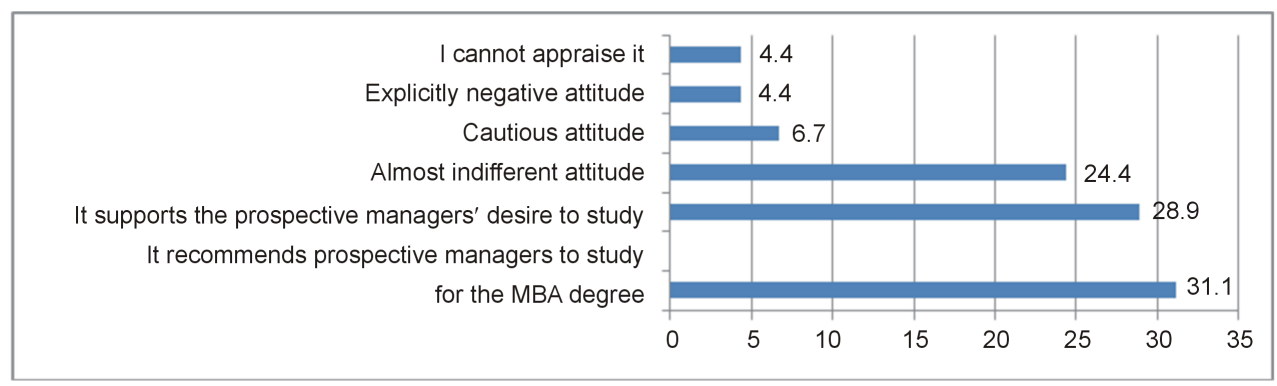

Figure 4. The attitude of the Administration to training under the MBA program (\%).

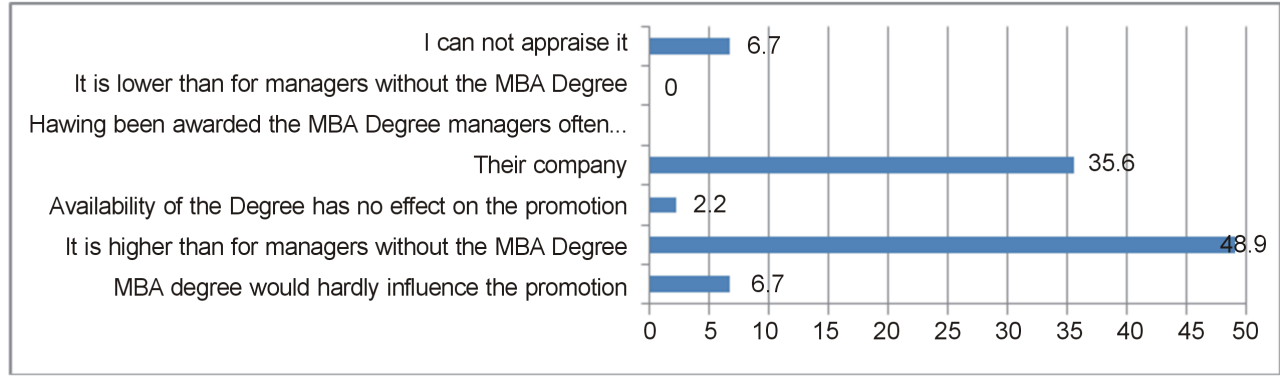

Figure 5. The rate of promotion in office for managers with the MBA degree (\%).

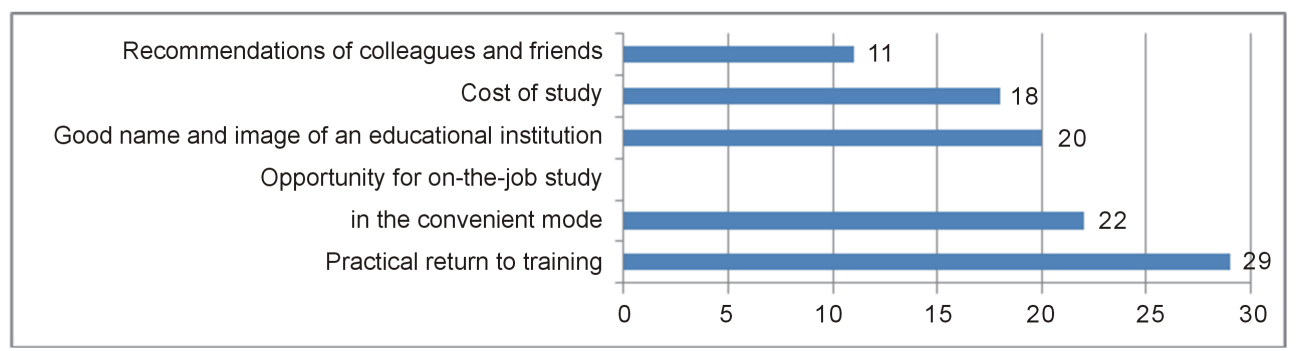

Figure 6. Decisive aspects for the MBA program selection (\%).

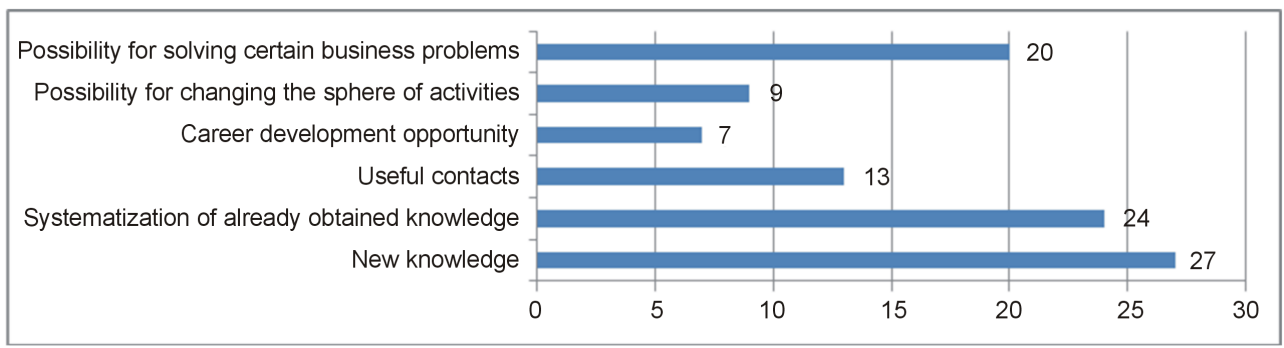

Figure 7. What do you get from the MBA program? (\%) 


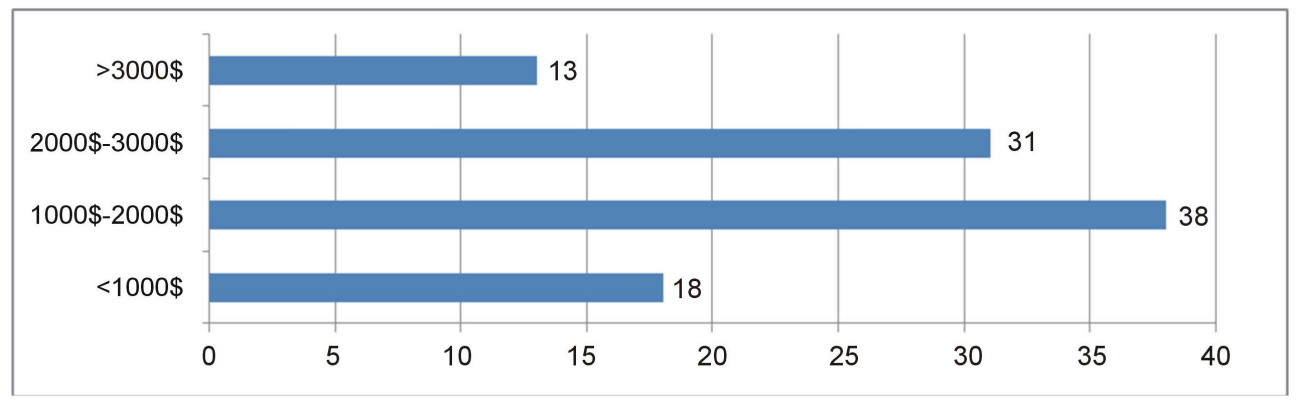

Figure 8. Respondents' income level (\%).

rest $13 \%$ of the respondents answer the put question as the opportunity to establish new business contacts. During the study under the MBA program the respondents' earnings are as follows: $18 \%$ of the respondents have earnings less than $\$ 1000$, 38\% of them have earnings from $\$ 1000$ to $2000,31 \%$ of the respondents earn $\$ 2000$ - 3000, the level of earnings for $13 \%$ amounts over $\$ 3000$ (Figure 9).

Over a half of the respondents (64\%) plan to increase their income by over $50 \%$ in a year after the award of the MBA degree, $27 \%$ of the trainees expect that a year later the Program completion their earnings will increase by $25 \%-50 \%$, but $9 \%$ think that their earnings will rise less than by $25 \%$.

Notwithstanding that $35.6 \%$ of the respondents consider the obtaining of the MBA degree as the incentive to the job change, $42 \%$ of them are going to proceed with work in the same place having obtained the Diploma of extended education. $31 \%$ of the respondents intend for sure to change their job and $27 \%$ of them expect the promotion in career.

Generally the students of the Program believe that the MBA Degree will give them advantages furthering their career development (73\%) but $27 \%$ of the respondents pass an opinion that knowledge obtained under the Program just will help in their work. So, what are the main motives for the training under the MBA program (Figures 10-13)?

The decisive motive is new knowledge (31\%), 24\% will study for future high earnings, for $20 \%$ of the respondents the MBA Program gives opportunities for the promotion, for $16 \%$ of them the opportunity to establish new business contacts is of major importance, and finally, the MBA Degree gives the chance for changing the sphere of activity. It is supposed by $9 \%$ of the respondents.

What are trainees based on when choosing a business school? What factors play the role in giving preference to any educational institutions?

The teaching staff ranks certainly the first (24\%). And it is true. In fact, $26.7 \%$ of the respondents would like first of all to get knowledge and skills in the sphere of administration. Rating positions rank the second (20\%).
A criterion of no little significance for choosing a business school is the cost of study. $18 \%$ of the respondents cast their votes thereto.

The location is also of importance (16\%). For $7 \%$ of the respondents the time of business school existing is important and $4 \%$ of them consider a financial support to be necessary for obtaining education. Answers to questions on problems and prospects of the business education are also of no little significance.

The improvement of the educational level is currently an indispensable condition of the managers' professionalism.

That is the opinion of the most respondents (62\%). $24 \%$ of them also rather agree thereto and $14 \%$ consider it rather true than indispensable.

Only $4.4 \%$ of the respondents have agreed to the statement that the present Russian education may give a little to the Russian business. $13.3 \%$ have considered this statement rather true. $31.1 \%$ have agreed thereto partially.

And the majority of the respondents (51.1\%) have not agreed at all $(22.2 \%)$ or partially $(28.9 \%)$ to this point of view. It is most probably conditioned by the internal competition or by the wish to study with the lack of funds to pay for it by oneself if no funding is provided by the company.

The lack of wish to study as such is also a probable version. But $49 \%$ of the respondents have not faced such a problem. The majority of trainees just need the certificate of graduation from an educational institution.

Only $4.4 \%$ of the respondents have agreed thereto and $11.1 \%$ of them have rather agreed than disagreed. $28.9 \%$ of the respondents have partially agreed that the majority just needs certificates of graduation (Figures 14-16).

Most of the respondents, however, believe that people strive first of all for improving the level of their knowledge. The opinions on the said matter have divided as follows: $31.1 \%$ have rather agreed to the statement and $24.4 \%$ have disagreed in full.

According to the research data $13 \%$ of the respondents have agreed or have rather agreed (7\%) to the statement that the availability of extended education certificates causes conflicts among the members of the staff. 31\% of 


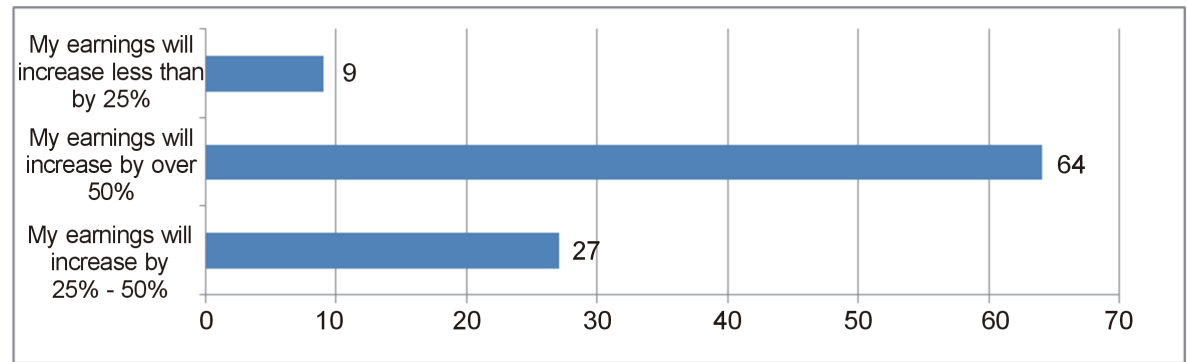

Figure 9. Planned income after the MBA program completion (\%).

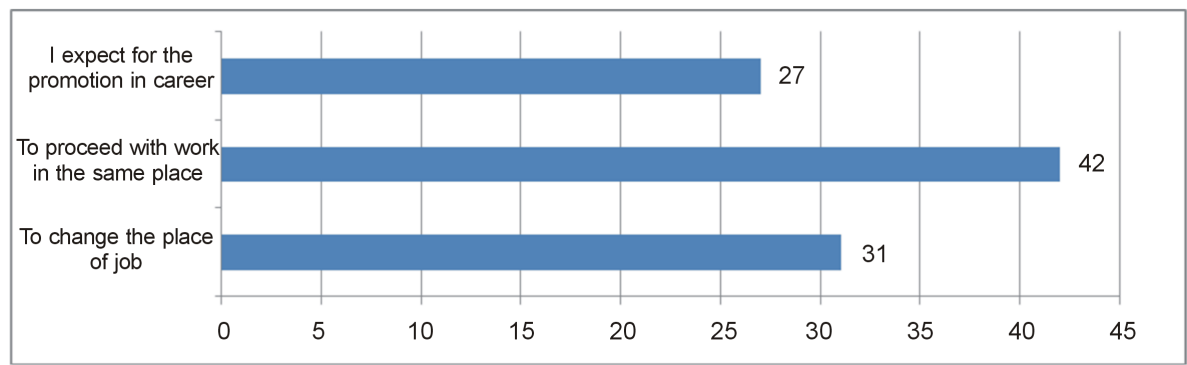

Figure 10. What are your plans after the completion of the MBA program? (\%)

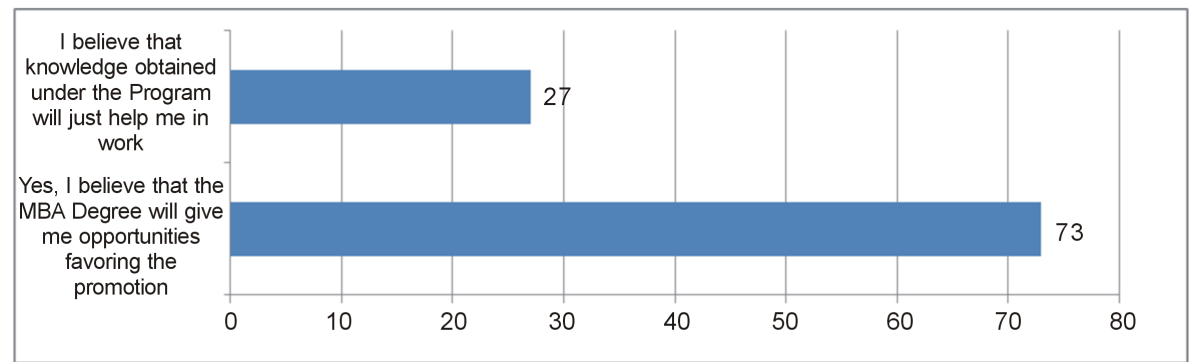

Figure 11. Will the MBA degree further the career development? (\%)

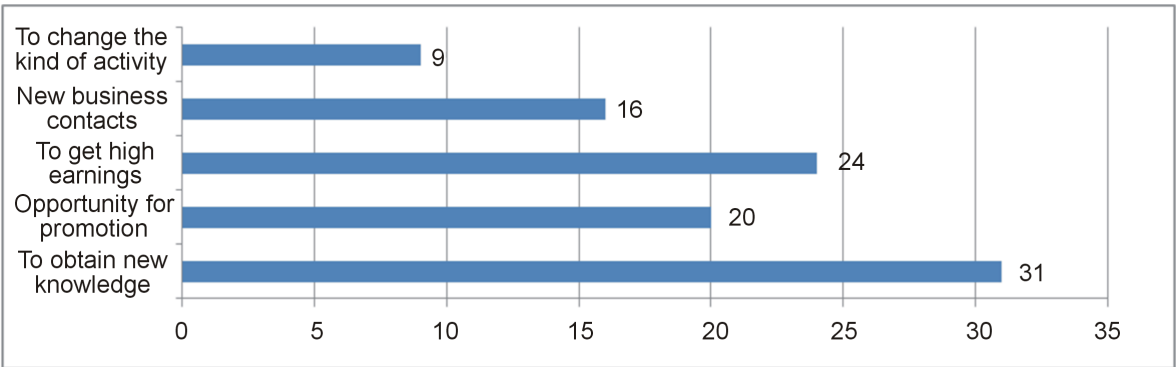

Figure 12. Motives for the training under the MBA program (\%).

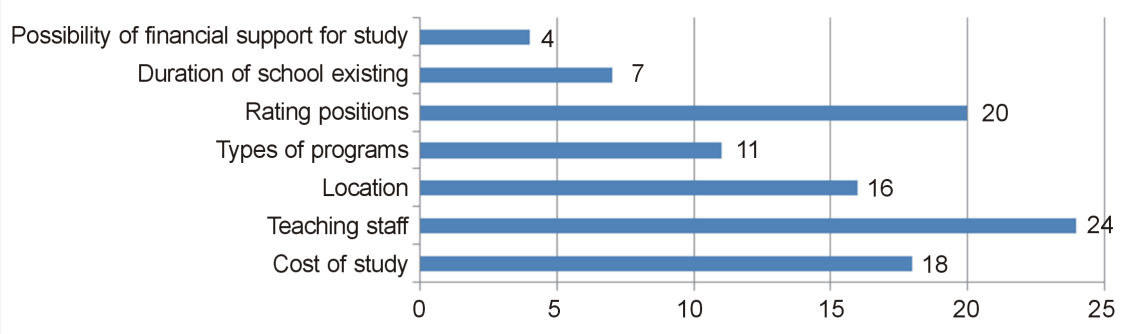

Figure 13. Criteria for choosing a business school (\%). 


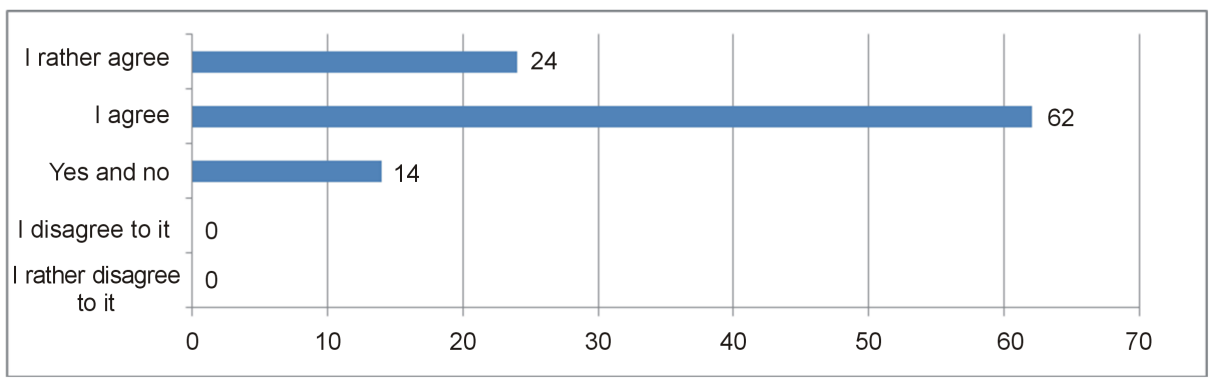

Figure 14. The improvement of the educational level is currently an indispensable condition of the managers' professionalism (\%).

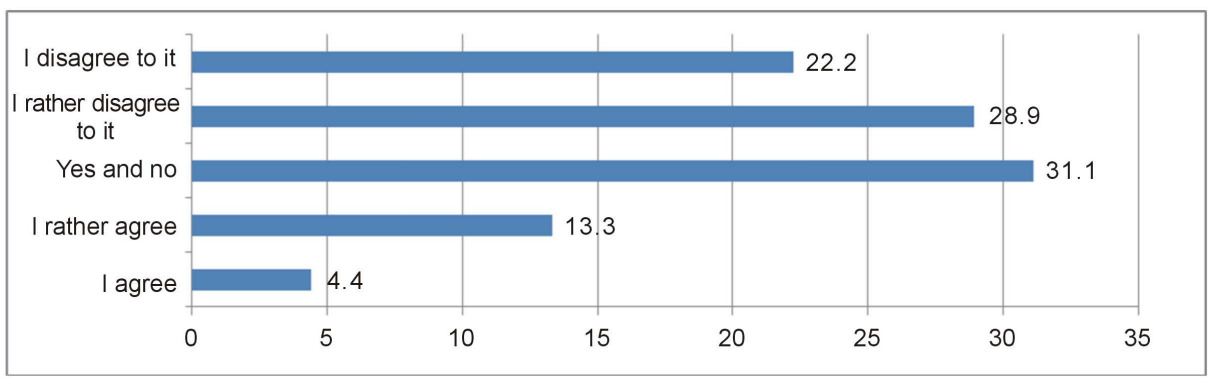

Figure 15. The present Russian education may give a little to the Russian business (\%).

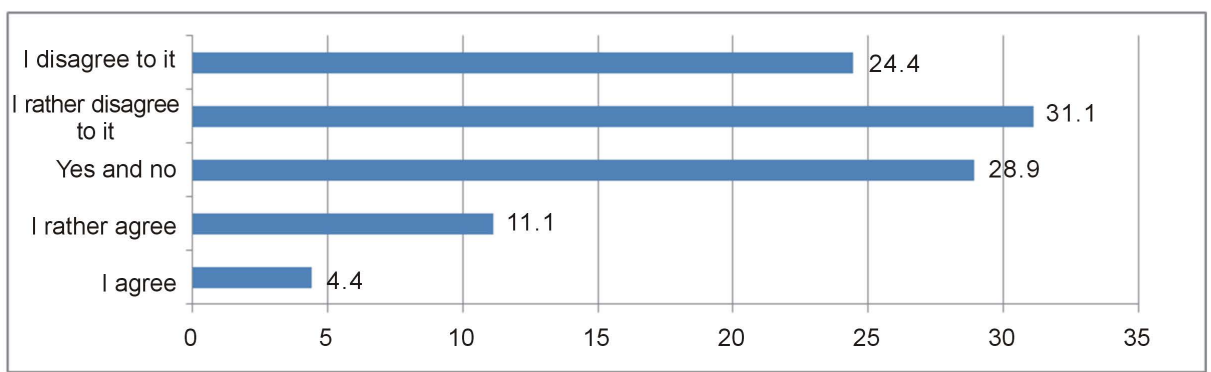

Figure 16. The majority of trainees just need the certificate of graduation from an educational institution (\%).

the respondents have also agreed thereto partially.

No disagreements have arisen when considering the statement that a company should promote the personnel for the MBA degree for raising its competitive capacity.

It is characteristic that nearly a half of the respondents (49\%) hold managerial positions such as company owners, managers of a large independent unit. It proves the fact that they will promote their employees to obtain extended education, namely the MBA degree.

Thus, $60 \%$ of the trainees have agreed or $33 \%$ of them have rather agreed to the said statement and only $7 \%$ of them have agreed thereto partially.

Fortunately, more and more executives today, as it has been noted before, arrive at the conclusion on the need of the qualification improvement and advance training both for them personally and for the whole managerial staff of the entity. Those companies where trainees of the MBA program are employed have a general idea of personnel development plans (51\%), in other companies such plans have been already elaborated in details (27\%).
$11 \%$ of the respondents have found it difficult to answer this question and $11 \%$ of them say that no personnel development plan is available in their company. Besides, the question on the need in the improvement of skills and knowledge was asked too.

On the average, $11.8 \%$ of managers do not need in the improvement of such branches as economy legislation, financial management, accounting, managerial accounting, business planning, project management, marketing, logistics, PC use, information management technologies application, knowledge of foreign languages, effective communication skills, PR, personnel management, working time arrangements and business etiquette knowledge.

- $12.9 \%$ of trainees do not practically need in the improvement of knowledge in the said branches.

- $16.3 \%$ of them have found it difficult to answer on some versions in the said branches.

- $34.4 \%$ suppose that the improvement of knowledge is a desired aspect and $26.8 \%$ of the respondents believe that the improvement of the said knowledge is highly 
necessary in some branches.

And the highest percentage of such «necessity» falls on the improvement of knowledge in such branches as business planning (46.7\%), personnel management (46.7\%), project management (42.2\%), effective communication skills (35.6\%) and working time arrangements (35.6\%). The majority of the trainees (42\%) find the accelerated 2 - 3-year education to be optimal.

Other respondents (38\%) believe that to obtain the MBA Degree one-year education programs are quite sufficient (38\%) (Figures 17-20).
$11 \%$ of them suppose that a few weeks will be an optimal period to obtain necessary knowledge and $9 \%$ of the trainees incline to the standard 5-year education.

The most effective forms of teaching, in the trainees' opinion, are trainings (29\%) and business games (27\%). For $16 \%$ of the respondents the arrangement of "round tables" is of great interest. $13 \%$ of them suppose that the examination of specific situations (cases) assists in the detailed consideration of possible business problems. $11 \%$ of them consider seminars to be an integral part of an effective form of the study.

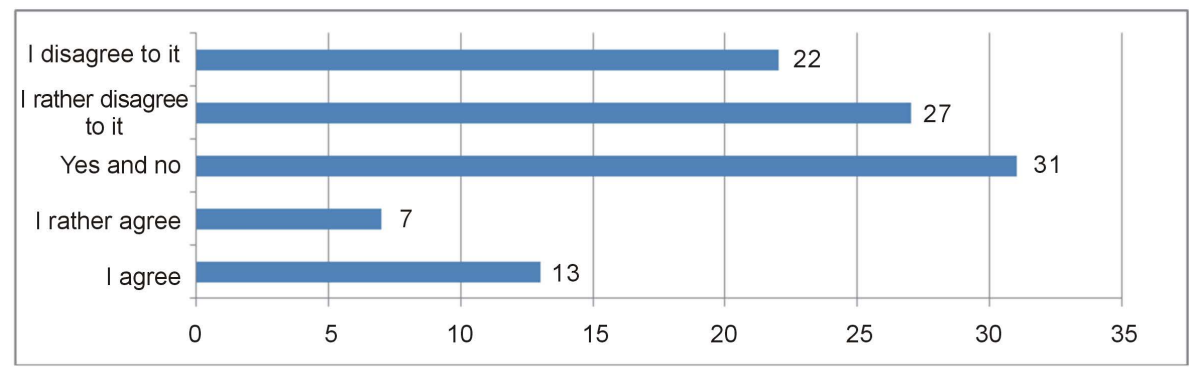

Figure 17. The availability of extended education certificates causes conflicts among the members of the staff (\%).

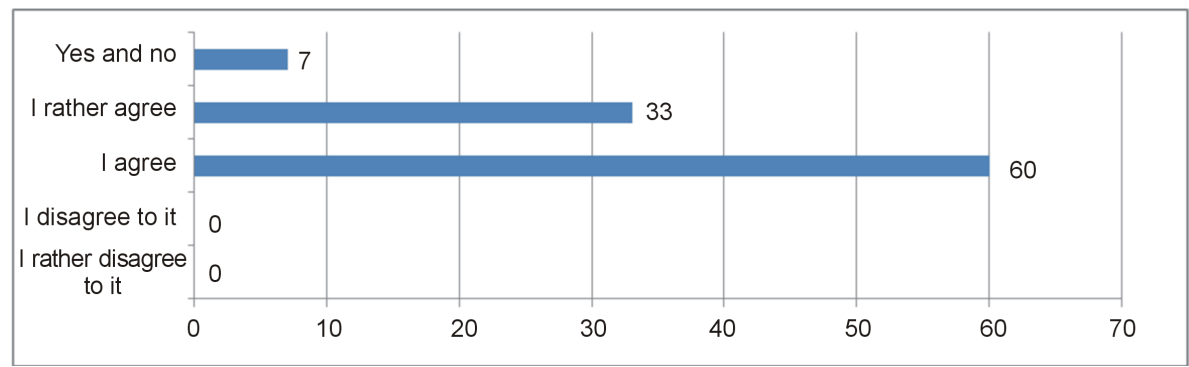

Figure 18. A company should promote the personnel for the MBA degree for raising its competitive capacity (\%).

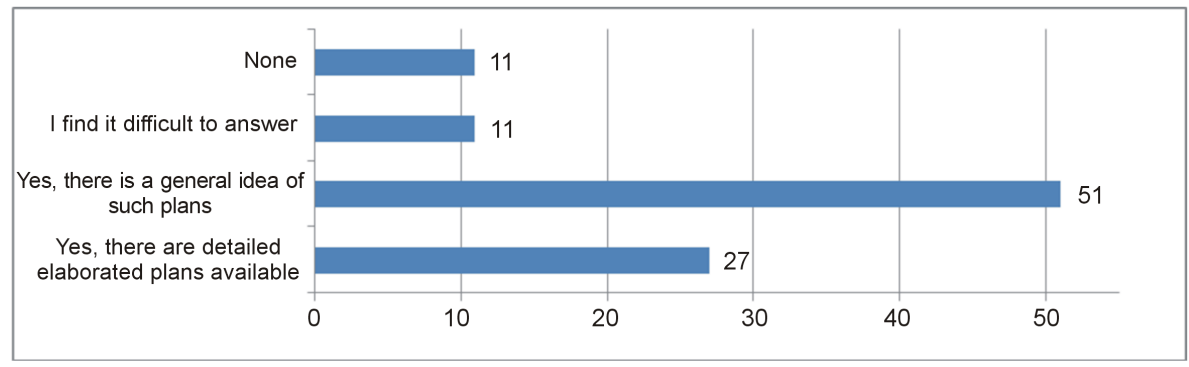

Figure 19. Are there personnel development plans available in your company? (\%)

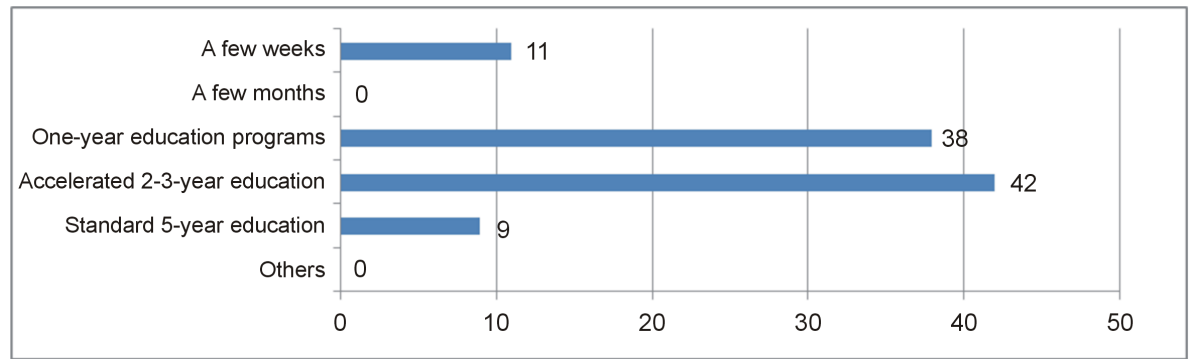

Figure 20. What period of study is optimal in your opinion? 
Only 4\% arrive at a conclusion that it is necessary to deliver lectures (Figure 21).

Problems arising in the personnel management consist, in the opinion of trainees involved in research, in the lack of skilled employees (38\%), in the unwillingness of specialists to further study (4\%), in no-motivation (27\%) and in the inadequacy of interests of an employee and a company (27\%). Among alternative versions of answers (4\%) there have been such as "the lack of work experience" and "adaptation problem” (Figures 22 and 23).

Nearly all the trainees have come to the same opinion that the business education is in demand (98\%) and only $2 \%$ have not agreed to the said statement for the reason of high cost of education. We may add the following to the above mentioned research results. In conclusion to the research data analysis it should be noted that the opinion of company owners and managers as prospective and current trainees under the MBA program makes the principals of the present Russian business schools to approach the education arrangement in a new way. A model of the current business education, a model of a teacher and business trainer are not assigned by an educational institution but are dictated by trainees exerting an active influence on the education process.

\section{Conclusions}

Besides, according to the research data under the crisis conditions, there is a serious tendency of a rising demand particularly in trainees and graduators of the MBA program for different companies of the region. On the other side, it should be noted that there is an increasing interest of prospective trainees to MBA programs (a similar tendency was observed in the second half of the eighties of the 20th century at once after the default).

The entrepreneurial community will lack knowledge in the sphere of the business development strategy in the nearest future.

The current generation of businessmen is greatly motivated for changing themselves, for obtaining new knowledge, for searching for effective business instruments. The demand in the high-level business education is currently

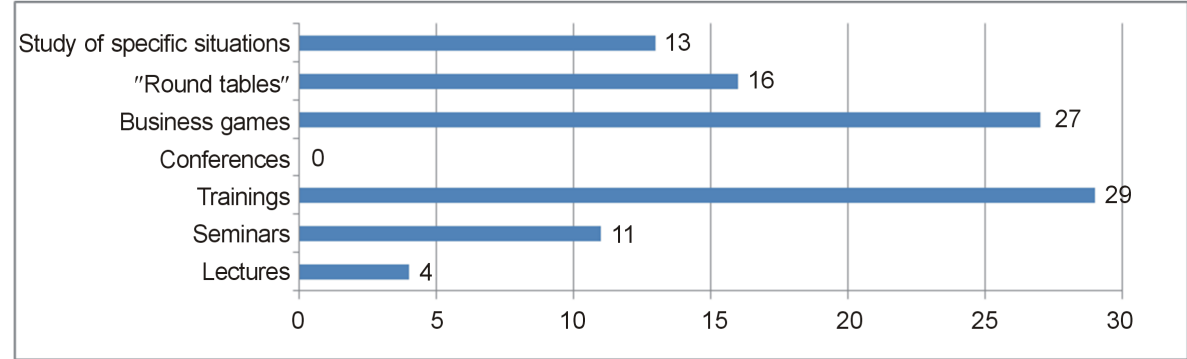

Figure 21. What forms of teaching are the most effective?

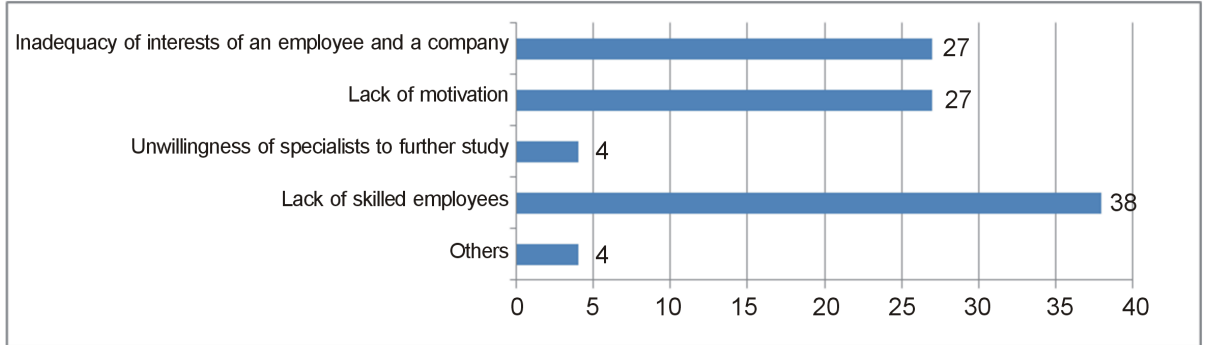

Figure 22. Problems in the personnel management (\%).



Figure 23. Is the business education in demand? 
urgent as it has never been before. Obviously, strategies for managing and educating of human resources need to be viewed as a holistic system of practices, with many interdependencies, which reflects the unique business goals and character of the organization.

Human resources represent a dynamic, shifting asset because the organization, its managers and individuals make daily choices that help to create, or potentially destroy value.

\section{REFERENCES}

[1] N. Klimova, "Innovative Clusters in Regional Economy," International Research Journal of Finance and Economics, Vol. 65, No. 4, 2011, pp. 6-10.

[2] N. Klimova and O. Kozyrev, "Distributed Educational Systems and Their Social Efficiency," European Journal of Economics, Finance and Administrative Sciences, Vol. 36, No. 8, 2011, pp. 105-109.

[3] N. Klimova and M. Litvintseva, "Universities Innovation Clusters: Approaches for National Competitiveness Para- digm,” European Journal of Social Sciences, Vol. 19, No. 1, 2011, pp. 160-162.

[4] O. Kozyrev, "Regional Clusters as the Form of Territorial Organization of Economy,” European Journal of Social Science, Vol. 21, No. 2, 2011, pp. 220-226.

[5] O. Kozyrev and P. Malyzhenkov, "Industrial Clusters as the Form of Territorial Organization of Economy in Russia and Italy," European Journal of Economics, Finance and Administrative Science, Vol. 42, No. 3, 2011, pp. 133-138.

[6] M. Litvintseva, "Methodology for Cluster Model Analysis for Technical and Workforce Needs of Companies in Universities Research Parks,” International Research Journal of Finance and Economics, Vol. 63, No. 3, 2011, pp. 63-69.

[7] N. Klimova and P. Malyzhenkov, "Spin-Off Phenomenon as a Factor of University Clusters Competitiveness Increasing: A Methodological Proposal,” Perspectives in $\mathrm{Bu}$ siness Informatics Research, 11th International Conference, BIR 2012, Springer, Berlin, 2012. 